Int. J. Electrochem. Sci., 12 (2017) 1550 - 1560

International Journal of

ELECTROCHEMICAL

SCIENCE

www.electrochemsci.org

\title{
A Simple Fabrication of Co (II)-phthalocyanine Modified Disposable Activated Screen Printed Carbon Electrode for the Effective Determination of L-cysteine
}

\author{
Karuppasamy Kohila rani ${ }^{1}$, Shen-Ming Chen ${ }^{2, *}$, Rajkumar Devasenathipathy ${ }^{1}$, Sea-Fue Wang ${ }^{1, *}$ \\ ${ }^{1}$ Department of Materials and Mineral Resources Engineering, No. 1, Sec. 3, Chung-Hsiao East Rd., \\ National Taipei University of Technology, Taipei, Taiwan \\ ${ }^{2}$ Electroanalysis and Bioelectrochemistry Lab, Department of Chemical Engineering and \\ Biotechnology, National Taipei University of Technology, No.1, Section 3, Chung-Hsiao East Road, \\ Taipei 106, Taiwan (R.O.C) \\ *E-mail:smchen78@ms15.hinet.net, sfwang@ntut.edu.tw
}

doi: $10.20964 / 2017.02 .74$

Received: 3 November 2016 / Accepted: 21 December 2016 / Published: 30 December 2016

\begin{abstract}
An amperometric electrochemical sensor for the sensitive detection of L-Cysteine was constructed using cobalt (II) tetrasulfonated phthalocyanine (CoTsPc) and activated screen printed carbon electrode (ASPCE) through a simple approach. The fabricated electrode was confirmed by field emission scanning electron microscopy (FESEM), energy-dispersive X-ray spectroscopy (EDX) and cyclic voltammetry $(\mathrm{CV})$. The sensitivity and selectivity of our modified electrode towards L-Cysteine were higher when compared to the performance of unmodified electrode. The experimental conditions for the electro-oxidation of L-Cysteine were optimized and the good electrocatalytic ability of our sensor was shown from the evaluated values of linear range (5 to $220 \mu \mathrm{M})$, LOD $(0.22 \mu \mathrm{M})$ and sensitivity $\left(953.8 \mu \mathrm{A} / \mathrm{mM} \mathrm{cm}^{-2}\right)$. In addition, our fabricated electrode selectively detects the L-Cysteine even in the presence of interfering other biomolecules. The satisfactory results for the demonstration of practical feasibility were also achieved with our modified electrode in human serum samples. An appreciable repeatability and reproducibility were attained by our fabricated electrode.
\end{abstract}

Keywords: cobalt (II) tetrasulfonated phthalocyanine, activated screen printed carbon electrode, LCysteine and sensitivity, practicality.

\section{$\underline{\text { FULL TEXT }}$}

(C) 2017 The Authors. Published by ESG (www.electrochemsci.org). This article is an open access article distributed under the terms and conditions of the Creative Commons Attribution license (http://creativecommons.org/licenses/by/4.0/). 